\title{
Impact of Corporate Governance on Investment in SMEs Vietnam
}

\author{
Nguyen Thi Kim Chi ${ }^{1}$, Bui Van $\mathrm{Can}^{1} \&$ Bui Minh Duc ${ }^{2}$ \\ ${ }^{1}$ Ha Noi University of Business and Technology, Hanoi, Vietnam \\ ${ }^{2}$ The University of Finance and Business Administration, Vietnam \\ Correspondence: Nguyen Thi Kim Chi, Ha Noi University of Business and Technology, 29A/124, Vinh Tuy Street, \\ Hai Ba Trung, Hanoi, Vietnam. Tel: 84-985-004-618. E-mail: chi.kkte@gmail.com
}

Received: September 25, 2019

Accepted: October 16, 2019

Online Published: October 25, 2019

doi:10.5539/ijef.v11n11p59

URL: https://doi.org/10.5539/ijef.v11n11p59

\begin{abstract}
Controlling the investment activities of company representatives helps to avoid inefficient investment activities. Shareholders will face with risks if manager's decisions which not bring benefits to shareholders (according to agency theory). Studying the influence of corporate governance on investment has an important role in controlling investment activities of enterprises. Therefore, the authors analyze the impact of corporate governance on investment of small and medium enterprises (SMEs) in Vietnam from 2014 to 2018. With data collected from 480 small and medium enterprises in Vietnam. The results show that state-owned enterprises tend to invest less than non-state enterprises. Companies with manager is board chair and manager hold shares will make investing more. Revenue growth and financial leverage have a positive impact on investment. From the results of this study, the authors also make some recommendations to help control investment activities in the enterprise through corporate governance characteristics.
\end{abstract}

Keywords: corporate governance, investment, SMEs

\section{Introduction}

The issue of interests of shareholders and agency of companies arise in the process of operation as well as investment in enterprises (Hartzell, Sun, \& Titman, 2006; Jensen \& Meckling, 1976). Therefore, enterprises will take measures to minimize this conflict of interest by controlling the activities of the executive board through the board of management's participation. In addition, enterprises also have proposals on the shared ownership of managers to create more responsibility for shareholders (Hartzell et al., 2006). The increase or decrease in the number of the board of directors and the board of directors in the executive role are also strategies used in business operations to bring about business efficiency (Morck, Shleifer, \& Vishny, 1988; Yermack, 1996).

The issue of agency costs, as well as the difference between the interests of the manager and the shareholders, makes the control of the board over the manager arise. The phenomenon of overinvestment is evident in companies with high levels of free cash flow. at this time, agency costs are more evident with these companies when the interests of managers and shareholders are considered to be conflict (Chen, Sun, \& Xu, 2016; Richardson, Mizruchi, \& Schwartz, 1989; Richardson, 2006). Therefore, corporate governance issues make a difference in decisions in general and investment in particular (Hartzell et al., 2006; Jensen \& Meckling, 1976). In the study of Chen et al. (2016), it was shown that state-owned enterprises had a higher level of overinvestment compared to other state-owned enterprises (SOEs). For underinvestments, the authors also point out that the company has a higher concentration of state ownership, a larger board sizes or higher rates of outside directors are associated with less serious investment (Chen et al., 2016).

Therefore, studying the impact of corporate governance on investment will help enterprises control their investment strategies effectively through corporate governance. Especially in the business environment in Vietnam, state-owned enterprises have their own characteristics that lead to different investment decisions than non-state enterprises. Therefore, this study will focus on assessing the impact of corporate governance on investment in small and medium enterprises in Vietnam.

\section{Literature Review}

Agency theory related to issues that may exist in a relationship between parties: between the chairman (shareholders) and agencies (chief executive officer_manager). The two problems solved by this theory include: 
The first problems arise when there are conflicts over the parties' goals; The problem arises when there is a difference in attitude towards risk (Eisenhardt, 1989; Ross, Westerfield, \& Jordan, 2008).

Stakeholder theory shows that there are many other stakeholders, including government agencies, political groups, trade associations, trade unions, communities, financial institutions, suppliers, employees, and customers. Therefore, the managers of companies should balance many different conflicts of different stakeholders while maximizing firm value (Donaldson \& Preston, 1995; Hill \& Jones, 1992). Some suggestions from the stakeholder theory are: Empowering shareholders to participate in important governance decisions; Change the composition of the board of directors by including many outside directors; Allows workers' representatives at certain levels of governance. However, like representation theory, the theory of stakeholders also has shortcomings due to its claims that the interests of many stakeholders can be compromised or balanced.

Stewardship theory, developed by Davis and Donaldson (1997), arises as a counterweight to agency theory, dealing with some of its limitations. This theory rejects personal interests, managers are more likely to serve the organization (Davis, Schoorman, \& Donaldson, 1997).

\section{Method}

\subsection{Research Model}

Referring to previous studies, the authors make a research model as follows:

$$
I N V_{i t}=\alpha+\beta_{i} G O V_{i t}+6 W_{i t}+u_{i t}
$$

Equation (1) shows the effect of variables on Investment, in which GOV (governance) variable is considered as an independent variable. $\mathrm{W}_{\mathrm{it}}$ are control variables. Details of the variables are described as follows

Table 1. Define the variables

\begin{tabular}{lcl}
\hline Variables & Symbol & \multicolumn{1}{c}{ Definition } \\
\hline $\begin{array}{l}\text { Dependent variable: } \\
\text { Investment }\end{array}$ & INV & Fixed asset purchase spending \\
Independent variables: & & $=1$ if State Ownership \\
State Ownership & State & $=0$ if opposite \\
Manager is shareholder & M_S & Number of manager is shareholder \\
Manager is board chair & M_B & Ratio of manager in board chair \\
\hline & \multicolumn{3}{c}{ W variables } \\
\hline Growth rate & GROWTH & (Revenue $\mathrm{t}-$ Revenue $\left._{\mathrm{t}-1}\right) /$ Revenue $_{\mathrm{t}-1}$ \\
Leverage & LEV & Debt/Equity \\
\hline
\end{tabular}

The calculation the variables are as follows:

Investment: equal to the total purchase of fixed assets in the year and divided by the total assets of the previous year.

\section{Corporate Governance:}

State (State Ownership): is a dummy variable with 1 being state-owned enterprises (state ownership over 50\%); other businesses are considered 0 (not belong to state ownership group). State-owned enterprises tend to invest less than non-state enterprises due to tighter investment control issues among state-owned enterprises.

M_S: The variable describing the number of managers holding shares. For enterprises that managers hold stocks, the investment activities will be increased when it comes to the interests of stockholders.

M_B: The ratio of manager is board chair

Growth rate measured by annual growth in revenue. Businesses with high revenue growth will be able to generate large cash flows. Therefore, investment in business development tends to increase

Leverage: Financial leverage is measured by the ratio of Liabilities/Equity. For enterprised with larger LEVs, the investment is more (Chen et al., 2016; He, Chen, \& Hu, 2019).

\subsection{Data Collection}

The secondary database is collected from audited financial statements of enterprises from 2014 to 2018 through FiinPro data system provided by StoxPlus Corporation (Only collect data of non-financial enterprises). 


\subsection{Methods of Data Analysis}

With analytical data characteristics for companies listed from 2014 to 2018, the panel data model will be used for analysis. The data, after had been collected, were input to the R software for analysis. Basic model, such as Fixed effect and Random effect were put in priority. Hausman test was used to find the right model for the real research data between Fixed effect and Random effect (Hausman, 1978). In case there were some problems in the models, such as autocorrelation, heteroscedasticity, endogeneity, we would use the robustness model (by xtscc syntax in STATA) to fix them.

\section{Result}

\subsection{Descriptive}

The research variables after collection will be import into STATA software to analysis. The descriptive statistics table shows that the average Investment value is 0.5 ; in which the largest is 117.98 and the smallest is 0 . The average rate of manager is board is 0.47 ; The largest is 0.87 and the smallest is 0.07 . The average number of managers who do not hold shares is 4 ; the largest is 15 and the smallest is 0 . Regarding average revenue growth is 0.39 ; The largest one is 224 and the smallest is 5.8 . The average leverage used by businesses is 0.48 ; in which the largest is 0.97 and the smallest is 0.23 .

Table 2. Descriptive the variables

\begin{tabular}{lcccc}
\hline Variable & Mean & Std. Dev. & Min & Max \\
\hline INV & 0.511766 & 3.288667 & 0 & 117.9832 \\
MANAGER_B & 0.472963 & 0.103828 & 0.071429 & 0.875 \\
MANAGER_S & 4.345342 & 2.867697 & 0 & 15 \\
GROWTH & 0.395887 & 5.894686 & -1 & 244.4558 \\
LEV & 0.480371 & 0.230407 & 0 & 0.970612 \\
\hline
\end{tabular}

\subsection{Regression}

In the panel data model, two FEM and REM models are implemented first. The Hausman test showed that the FEM model is more suitable than REM model (p-value of less than 0.05). The autocorrelation tests and heteroskedasticity all exist in the FEM model. Therefore, the calibration model with the xtscc statement is made to produce a reliable model. The analytical results will be based on this correction model.

Table 3. The result of the regression

\begin{tabular}{|c|c|c|c|}
\hline VARIABLES & $\begin{array}{c}\text { (1) } \\
\text { FEM }\end{array}$ & $\begin{array}{c}(2) \\
\text { REM }\end{array}$ & $\begin{array}{c}\text { (3) } \\
\text { Robustness } \\
\end{array}$ \\
\hline \multirow[t]{2}{*}{ STATE } & -0.496 & -0.317 & $-0.496^{*}$ \\
\hline & $(0.396)$ & $(0.206)$ & $(0.275)$ \\
\hline \multirow[t]{2}{*}{ M_B } & $3.880^{*}$ & 0.348 & $3.880 * * *$ \\
\hline & (2.325) & $(0.894)$ & $(1.362)$ \\
\hline \multirow[t]{2}{*}{ M_S } & 0.0656 & 0.0387 & $0.0656^{* * *}$ \\
\hline & $(0.0539)$ & $(0.0298)$ & $(0.0251)$ \\
\hline \multirow[t]{2}{*}{ GROWTH } & $0.0422 *$ & $0.0535^{* *}$ & $0.0422 * * *$ \\
\hline & $(0.0253)$ & $(0.0236)$ & $(0.00929)$ \\
\hline \multirow[t]{2}{*}{ LEV } & $1.588^{*}$ & 0.173 & $1.588 * * *$ \\
\hline & $(0.826)$ & $(0.388)$ & $(0.521)$ \\
\hline \multirow[t]{2}{*}{ Constant } & $-2.281 *$ & 0.168 & $-2.281 * * *$ \\
\hline & $(1.211)$ & $(0.524)$ & $(0.757)$ \\
\hline Observations & 2,358 & 2,358 & 2,358 \\
\hline Number of groups & 480 & 480 & 480 \\
\hline Hausman test & & 0.000 & \\
\hline Heteroskedasticity & & 0.000 & \\
\hline Autocorrelation & & 0.000 & \\
\hline
\end{tabular}

Standard errors in parentheses: $* * * \mathrm{p}<0.01, * * \mathrm{p}<0.05, * \mathrm{p}<0.1$ 
Regression analysis results show that STATE has a negative impact on Investment (negative beta and p-value is less than 0.05). The results of this study show that SOEs have a lower level of investment than non-state enterprises. In recent years, state-owned enterprises have restricted their investments when the case was related to Dinh La Thang in VPN. Therefore, the operation of businesses is more strictly controlled and also more careful in investment decisions. Non-state ownership enterprises have a higher level of investment due to the use of capital is decided faster when there is high profitability.

The manager in board chair (M_B) has a positive impact on investment (positive beta and p-value is less than 0.05). For businesses with manager is Board, the investment is higher than enterprises without manager as chairman of the board. In this case, the manager made the investment decisions associated with personal interests. Therefore, investment decisions tend to increase stronger than other businesses. Maybe businesses have overconfidence in their investment decisions. Managers have been expecting the development of their investment projects. Expect better business results to increase stock value as well as company value, dividend payout ratio also increases to benefit shareholders.

For businesses with more managers holding shares (M_S), the more investment there is (positive beta and p-value is less than 0.05). Like manager is Board, manager so their decisions always bring high expectations in the future to increase the value of stocks as well as benefit shareholders.

Revenue growth (GROWTH) has a positive effect on investment (positive beta and p-value is less than 0.05). Enterprises with good performance bring high revenue growth, leading to more investment. The greater the cash flow generated in the enterprises, the easier it will be for enterprises to make investment decisions. At the same time, when the business achieves good growth, sustainable development strategies will always be put in place to maintain future performance. Therefore, these enterprises tend to invest more.

Financial leverage (LEV) has a positive effect on investment (positive beta and p-value is less than 0.05). The results of this study indicate that enterprises are inclined to use loans to invest in activities. In other words, enterprises are using the tax shield in their business activities in general and investment activities in particular. The tax shield is a strategic channel that enterprises use in leveraging capital cost deduction as well as taking advantage of external loans instead of fully utilizing capital within the enterprises.

\section{Conclusion}

With the regression analysis technique, the authors have shown evidence of the impact of Governance on investment. In particular, state-owned enterprises have lower investment levels than non-state enterprises. This makes it possible for SOEs to adjust their investment strategies but need to be efficient to scale up compared to non-state enterprises. The fact, manager is Board chair and manager is shareholder has a positive impact on investment shows that managers with a stake in the company will have a higher investment because of confidence. Therefore, businesses need to have tighter control of overinvestment due to the overconfidence of the manager.

\section{References}

Chen, X., Sun, Y., \& Xu, X. (2016). Free cash flow, over-investment and corporate governance in China. Pacific-Basin Finance Journal, 37, 81-103. https://doi.org/10.1016/j.pacfin.2015.06.003

Davis, J. H., Schoorman, F. D., \& Donaldson, L. (1997). Toward a stewardship theory of management. Academy of Management Review, 22(1), 20-47. https://doi.org/10.5465/amr.1997.9707180258

Donaldson, T., \& Preston, L. E. (1995). The Stakeholder Theory of the Corporation: Concepts, Evidence, and Implications. Academy of Management Review, 20(1), 65-91. https://doi.org/10.5465/amr.1995.9503271992

Eisenhardt, K. M. (1989). Agency Theory: An Assessment and Review. Academy of Management Review, 14(1), 57-74. https://doi.org/10.5465/amr.1989.4279003

Hartzell, J. C., Sun, L., \& Titman, S. (2006). The Effect of Corporate Governance on Investment: Evidence from Real Estate Investment Trusts. Real Estate Economics, 34(3), 343-376. https://doi.org/10.1111/j.1540-6229.2006.00170.x

Hausman, J. A. (1978). Specification Tests in Econometrics. Econometrica, 46(6), 1251-1271. https://doi.org/10.2307/1913827

He, Y., Chen, C., \& Hu, Y. (2019). Managerial overconfidence, internal financing, and investment efficiency: Evidence from China. Research in International Business and Finance, 47, 501-510. https://doi.org/10.1016/j.ribaf.2018.09.010 
Hill, C. W. L., \& Jones, T. M. (1992). Stakeholder-Agency Theory. Journal of Management Studies, 29(2), 131-154. https://doi.org/10.1111/j.1467-6486.1992.tb00657.x

Jensen, M. C., \& Meckling, W. H. (1976). Theory of the firm: Managerial behavior, agency costs and ownership structure. Journal of Financial Economics, 3(4), 305-360. https://doi.org/10.1016/0304-405X(76)90026-X

Morck, R., Shleifer, A., \& Vishny, R. W. (1988). Management ownership and market valuation: An empirical analysis. Journal of Financial Economics, 20, 293-315. https://doi.org/10.1016/0304-405X(88)90048-7

Richardson, R. J., Mizruchi, M. S., \& Schwartz, M. (1989). Intercorporate Relations: The Structural Analysis of Business. Administrative Science Quarterly, 34(1), 149. https://doi.org/10.2307/2392995

Richardson, S. (2006). Over-investment of free cash flow. Review of Accounting Studies, 11(2), $159-189$. https://doi.org/10.1007/s11142-006-9012-1

Ross, S. A., Westerfield, R., \& Jordan, B. D. (2008). Fundamentals of Corporate Finance. Retrieved February 26, 2019, from https://www.amazon.co.uk/Corporate-Finance-David-Hillier/dp/0077121155

Yermack, D. (1996). Higher market valuation of companies with a small board of directors. Journal of Financial Economics, 40(2), 185-211. https://doi.org/10.1016/0304-405X(95)00844-5

\section{Copyrights}

Copyright for this article is retained by the author(s), with first publication rights granted to the journal.

This is an open-access article distributed under the terms and conditions of the Creative Commons Attribution license (http://creativecommons.org/licenses/by/4.0/). 